\title{
Changes in paediatric resuscitation knowledge among doctors
}

\author{
D Carapiet, J Fraser, A Wade, P W Buss, R Bingham
}

\begin{abstract}
Aims-To investigate whether paediatricians have improved their resuscitation knowledge since 1992, and whether those who have attended a paediatric resuscitation course have greater knowledge than those who have not.

Methods-Telephone survey of 94 resident paediatricians admitting emergency cases. Questions on clinical scenarios were asked and adherence to internationally agreed guidelines in answering was determined.

Results-There were significantly more correct answers to $9 / 10$ questions in 1999 compared to 1992. The 1999 doctors who had attended a course scored significantly better in 3/10 questions and achieved a higher total score ( 5.43 versus 4.55 ). Conclusions-Knowledge has improved since 1992; this has been over the period in which paediatric resuscitation courses were introduced. In 1999 those who had been on a course were more knowledgeable than those who had not.

(Arch Dis Child 2001;84:412-414)
\end{abstract}

Keywords: resuscitation; life support courses; education

Paediatric Intensive

Care, Bristol Royal

Hospital for Sick

Children, St Michaels

Hill, Bristol BS2 8BJ,

UK

J Fraser

Department of Paediatric

Epidemiology \&

Biostatistics, Institute

of Child Health, 30

Guilford St, London

WC1N 1EH, UK

A Wade

Department of

Paediatrics, Royal

Gwent Hospital,

Cardiff Rd, Newport,

Gwent NP9 2UB, UK

PW Buss

Department of

Anaesthesia, Great

Ormond Street

Hospital, 30 Guilford

St, London

WC1N 1EH, UK

R Bingham

Correspondence to:

Dr D Carapiet, Department

of Anaesthesia, Queen

Alexandra Hospital,

Portsmouth PO6 3LY, UK

Accepted 16 November 2000 These courses are recommen all paediatricians in training as well as doctors

Table 1 Questionnaire with acceptable answers, 1992 and 1999 in other specialties who look after children. ${ }^{23}$ We repeated the original survey to determine whether trainee paediatricians in 1999 have a better level of resuscitation knowledge compared to their 1992 counterparts.

\section{Methods}

Our survey closely simulated the 1992 study in terms of design of study, numbers of doctors targeted, and geographical region. We undertook a telephone survey of the most senior resident paediatrician on two separate days in 47 hospitals accepting acute paediatric emergencies across four separate regions: Wales, the South West, Wessex, and the West Midlands. The 94 individuals ranged from senior house officer to senior registrar grade. Each respondent was asked their grade, certification of APLS or PALS course, and eight clinical questions (table 1). The interviewers, DC (specialist registrar in paediatric anaesthesia) and JF (specialist registrar in paediatric intensive care) were both experienced in the resuscitation of critically ill children, and each was allocated two different regions. Acceptable answers were based upon APLS, PALS, advanced trauma life support (ATLS), and European Resuscitation Council (ERC) guidelines ${ }^{4-7}$ (see table 1). We assigned a score of one mark for each correct answer, giving a possible maximum score of eight. All parts of question 1 needed to be correct to qualify for a mark.

Fisher's exact test was used to compare the percentage of correctly answered individual questions between 1992 and 1999. Individual paediatricians' results and seniority status were not available from 1992 for comparison. Multiple regression was used to investigate the 1999 score totals while adjusting for the registrar status of the respondents. A p value of less

\begin{tabular}{|c|c|c|}
\hline Question & Acceptable answer range, 1992 & Acceptable answer range, 1999 \\
\hline $\begin{array}{l}\text { What size tracheal tube would you use in a child of } \\
\text { 1a) } 3 \text { months? }\end{array}$ & $3-4.5 \mathrm{~mm}$ & $3-4.5 \mathrm{~mm}$ \\
\hline 1b) 4 years? & $4-5.5 \mathrm{~mm}$ & $4-5.5 \mathrm{~mm}$ \\
\hline 1c) 8 years? & $5-6.5 \mathrm{~mm}$ & $5-6.5 \mathrm{~mm}$ \\
\hline $\begin{array}{l}2 \text { If necessary what dose } / \mathrm{kg} \text { of adrenaline would you use in } \\
\text { arrest procedures? }\end{array}$ & $0.1-0.5 \mathrm{ml} / \mathrm{kg}$ of $1 / 10000$ & $0.1 \mathrm{ml} / \mathrm{kg}$ of $1 / 10000$ \\
\hline $\begin{array}{l}3 \text { In a child who arrives following freshwater drowning, } \\
\text { asystolic with fixed dilated pupils, but intubated at scene } \\
\text { by paramedics, for how long would you consider } \\
\text { resuscitation appropriate? }\end{array}$ & Hypothermia correction & Hypothermia correction \\
\hline $\begin{array}{l}4 \text { For resuscitation in severe haemorrhage }(30 \% \text { blood } \\
\text { loss), what would be the fluid volume } / \mathrm{kg} / \text { unit time? }\end{array}$ & $15-30 \mathrm{ml} / \mathrm{kg}$ over $30 \mathrm{~min}$ & $20 \mathrm{ml} / \mathrm{kg}$ stat \\
\hline $\begin{array}{l}5 \text { Do you know a formula for fluid replacement in severe } \\
\text { burns? }\end{array}$ & Any verifiable formula & Any verifiable formula \\
\hline $\begin{array}{l}6 \text { In a severely shocked child where you are unable to gain } \\
\text { venous access, how would you gain vascular access? }\end{array}$ & Intraosseus access & Intraosseus access \\
\hline $\begin{array}{l}7 \text { In a multiply injured child (road traffic accident), what } \\
\text { three } x \text { rays would you most like to see? }\end{array}$ & Chest + cervical spine & Chest, cervical spine, and pelvis \\
\hline $\begin{array}{l}8 \text { In a child with a severe airway obstruction (epiglottitis), } \\
\text { where bag and mask ventilation is ineffective and } \\
\text { intubation failed, how would you gain airway access? }\end{array}$ & Cricothyriodotomy & Cricothyriodotomy \\
\hline
\end{tabular}


Table 2 Percentage of correctly answered questions comparing 1992 and 1999, 1992 and 1999 course non-attendees, and 1999 course attendees versus non-attendees

\begin{tabular}{|c|c|c|c|c|c|c|c|c|c|}
\hline \multirow[b]{2}{*}{ Question } & \multicolumn{3}{|c|}{1992 v total 1999} & \multicolumn{3}{|c|}{1992 v 1999 non-course } & \multicolumn{3}{|c|}{1999 course v 1999 non-course } \\
\hline & $\begin{array}{l}1992 \\
\% \text { correct } \\
(n=73)\end{array}$ & $\begin{array}{l}1999 \\
\% \text { correct } \\
(n=91)\end{array}$ & $\begin{array}{l}\mathrm{CI}^{\star} \\
p \text { value }\end{array}$ & $\begin{array}{l}1992 \\
\% \text { correct } \\
(n=73)\end{array}$ & $\begin{array}{l}1999 \\
\% \text { correct } \\
(n=22)\end{array}$ & $\begin{array}{l}\mathrm{CI}^{\star} \\
p \text { value }\end{array}$ & $\begin{array}{l}\text { Course } \\
\% \text { correct } \\
(n=69)\end{array}$ & $\begin{array}{l}\text { Non-course } \\
\% \text { correct } \\
(n=22)\end{array}$ & $\begin{array}{l}\mathrm{CI}^{\star} \\
p \text { value }\end{array}$ \\
\hline $1 \mathrm{a}$ & 82 & 97 & $\begin{array}{l}(5,24) \\
0.002\end{array}$ & 82 & 86 & $\begin{array}{l}(-13,21) \\
0.463\end{array}$ & 100 & 86 & $\begin{array}{l}(-1,28) \\
0.0126\end{array}$ \\
\hline $1 b$ & 63 & 76 & $\begin{array}{l}(1,27) \\
0.054\end{array}$ & 63 & 64 & $\begin{array}{l}(-22,24) \\
0.583\end{array}$ & 80 & 64 & $\begin{array}{l}(-6,38) \\
0.108\end{array}$ \\
\hline $1 \mathrm{c}$ & 45 & 68 & $\begin{array}{l}(8,38) \\
0.003\end{array}$ & 45 & 64 & $\begin{array}{l}(-4.7,42) \\
0.101\end{array}$ & 70 & 64 & $\begin{array}{l}(-17,29) \\
0.393\end{array}$ \\
\hline 2 & 52 & 81 & $\begin{array}{l}(15,43) \\
<0.0005\end{array}$ & 52 & 59 & $\begin{array}{l}(-17,31) \\
0.369\end{array}$ & 88 & 59 & $\begin{array}{l}(7,51) \\
0.004\end{array}$ \\
\hline 3 & 27 & 60 & $\begin{array}{l}(19,47) \\
<0.0005\end{array}$ & 27 & 68 & $\begin{array}{l}(19,63) \\
0.001\end{array}$ & 58 & 68 & $\begin{array}{l}(-33,13) \\
0.275\end{array}$ \\
\hline 4 & 49 & 74 & $\begin{array}{l}(10,39) \\
0.001\end{array}$ & 49 & 59 & $\begin{array}{l}(-14,33) \\
0.288\end{array}$ & 78 & 59 & $\begin{array}{l}(-4,42) \\
0.070\end{array}$ \\
\hline 5 & 0 & 7 & $\begin{array}{l}(2,12) \\
0.027\end{array}$ & 0 & 5 & $\begin{array}{l}(-4,13) \\
0.232\end{array}$ & 7 & 5 & $\begin{array}{l}(-8,13) \\
0.551\end{array}$ \\
\hline 6 & 26 & 100 & $\begin{array}{l}(64,84) \\
<0.0005\end{array}$ & 26 & 100 & $\begin{array}{l}(64,84) \\
<0.0005\end{array}$ & 100 & 100 & $\begin{array}{l}(-10,19) \\
1.00\end{array}$ \\
\hline 7 & 23 & 59 & $\begin{array}{l}(22,50) \\
<0.0005\end{array}$ & 23 & 46 & $\begin{array}{l}(-1,45) \\
0.042\end{array}$ & 64 & 46 & $\begin{array}{l}(-5,42) \\
0.102\end{array}$ \\
\hline 8 & 44 & 79 & $\begin{array}{l}(21,49) \\
<0.0005\end{array}$ & 44 & 59 & $\begin{array}{l}(-8,39) \\
0.155\end{array}$ & 86 & 59 & $\begin{array}{l}(4,49) \\
0.012\end{array}$ \\
\hline
\end{tabular}

$\star 95 \%$ CI for difference.

than 0.05 was considered significant and all differences are presented with $95 \%$ confidence intervals (CI).

\section{Results}

A total of 91/94 (97\%) paediatricians contacted in 1999 participated in the study. There were more correct answers to all questions in 1999 compared to 1992 (table 2).

- Question 1. Paediatricians continue to estimate the tracheal tube size more accurately in the younger child compared to the older

- Question 2. Although there was a significant improvement in the knowledge of the correct adrenaline dose, $19 \%$ of paediatricians in 1999 still suggested an incorrect dose

- Question 3. There was a greater understanding of the importance of prolonged resuscitation in hypothermia

- Question 4. There was a better understanding of volume replacement for severe haemorrhage in 1999, with many paediatricians mentioning the importance of patient reassessment

- Question 5. Very few doctors in both 1992 and 1999 could quote a formula for fluid replacement in burns

- Question 6. The use of the intraosseous site for gaining vascular access has increased greatly since 1992, with all 1999 respondents suggesting its use

- Question 7. The appropriate use of radiological imaging for major trauma was better understood by 1999 respondents

- Question 8. The indication for cricothyroidotomy in patients with severe upper airway obstruction was better understood in 1999 than in 1992.

Comparison between 1992 and the subgroup of the 1999 sample who had not attended a course provided a measure of noncourse related changes over time. The noncourse attendees in 1999 answered all questions correctly more frequently than the 1992 group. For questions 3, 6, and 7 this difference was significant.

Among the 1999 respondents, all questions except 3 and 6 were answered correctly more frequently by those doctors who had completed a course. The difference was significant for questions 1a, 2, and 8. Those who had attended a course in 1999 had a higher total score compared to those who had not attended (5.43 v 4.55; 95\% CI 0.12, 1.66; $\mathrm{p}=0.023)$. A higher proportion of the doctors questioned in 1999 were registrars $(63 / 91 ; 69 \%)$ compared to the 1992 cohort $(37 / 73 ; 51 \%)$. The registrars tended to get higher scores and were also more likely to have been on a course. If registrar status was accounted for, course attendance was no longer significant (difference $0.74 ; 95 \%$ CI $-0.02,1.5 ; \mathrm{p}=0.0566)$.

\section{Discussion}

There is much debate as to whether resuscitation courses result in practical improvement in knowledge. In a review of 17 studies of life support courses, $5 / 8$ studies failed to show any significant gain in knowledge, and $8 / 9$ studies failed to show any significant net gain in scores of skills performance between pre and postcourse follow up testing. ${ }^{8}$ Retention of knowledge and skills declines from as early as three months.

Our study shows that, since 1992, paediatric resuscitation knowledge has significantly improved. Comparing the 1992 data with the subgroup of 1999 who had not attended a course shows an overall improvement regardless of APLS/PALS course attendance. The 1999 data show a higher total score among those attending a course, and that paediatricians who had completed a resuscitation course answered some questions (1a, 2, and 8) significantly better. This improvement was less pronounced when registrar status was taken into account and it may be that self selection occurs, whereby the more motivated and experienced paediatrician attends an APLS/PALS 
course, and these individuals may have better resuscitation knowledge anyway.

We do not know if this improved knowledge results in improved outcome. However, Roberts and colleagues ${ }^{9}$ have shown a substantial decline in hospital deaths for children admitted with severe injury between 1989 and 1995 and suggested that this may be a result of better initial assessment and resuscitation in hospital.

From this study, we cannot prove conclusively that the introduction of paediatric resuscitation courses in the UK has been responsible for the improvement in knowledge. There is also no guarantee that knowledge of resuscitation guidelines translates into improved patient outcomes, although there has been a coincident reduction in the in-hospital mortality following trauma during the study period.
1 Buss PW, McCabe M, Evans RJ, et al. A survey of basic resuscitation knowledge among resident paediatricians. Arch Dis Child 1993;68:75-8.

2 Royal College of Surgeons. Higher specialist training in paediatric surgery. Curriculum educational content and structure of training programmes. London: Specialist Advisory Committee, Royal College of Surgeons, 1997.

3 Callum KG, Gray AJG, Hoile RW, et al. Extremes of age. The 1999 Report of the National Confidential Enquiry into Perioperative Deaths. London: National Confidential Enquiry into Perioperative Deaths, 1999.

4 Advanced Life Support Group. Advanced paediatric life support. The practical approach, 2nd edn. London: BMJ port. The practical approad
Publishing Group, 1997.

5 American Academy of Pediatrics, American Heart Association. Pediatric advanced life support, 1997-1999. USA: American Heart Association, 1999.

6 American College of Surgeons. Advanced Trauma Life Support Course. American College of Surgeons, 1997.

7 European Resuscitation Council. European resuscitation council guidelines for resuscitation. Antwerp: Elsevier, 1998.

8 Jabbour M, Osmond MH, Klassen TP. Life support courses: are they effective? Ann Emerg Med 1996;28:690-8.

9. Roberts I Campbell F, Hollis S, Yates D. Reducing accident Roberts I, Campbell F, Hollis S, Yates D. Reducing accident of hospital care. BMF 1996;313:1239-41.

\section{Paediatricians, powerful others, and loci of control}

You are on $£ 16000$. If you answer the next question correctly you will take home at least $£ 32000$. The question is: "what is your health locus of control?" Is it (a) your GP's surgery, (b) a newly discovered brain stem centre which increases its neuronal firing rate when you are ill, (c) your beliefs about who or what is most important in keeping you well, or (d) the National Institute for Clinical Excellence (NICE). Not sure? Better phone your old friend Archie, who for a mere ten per cent cut will tell you the answer is (c). What is more, he will tell you that it can be measured using the MHLC (Multidimensional Health Locus of Control) scale. (Why is it "health locus of control" and not "locus of health control" or even "control locus of health", I wonder?)

This 18 item scale measures your beliefs about who or what controls your health; yourself, doctors or other health professionals ("powerful others"), or chance. Since doctors (all of them except you and me, of course) tend towards egotism and cynicism, you might expect them to score highly in the first and third of these belief categories. The care that medics arrange for themselves has been related to MHLC score and medical speciality in an American study (Cary P Gross and colleagues. Archives of Internal Medicine 2000;160:3209-14).

A cohort of 1948-64 graduates of Johns Hopkins Medical School were followed up, assessing their "regular source of care" (RSOC) in 1991 and use of routine services in 1997. Now, we all know that paediatricians (even you and I) are the good boys and girls of medicine, and so it proved. Forty six per cent of pathologists, $39 \%$ of physicians, and $34 \%$ of surgeons, but only $22 \%$ of paediatricians (and $21 \%$ of psychiatrists) had no RSOC. Not having an RSOC went along with high MHLC scores for self or chance as determinants of health. So presumably paediatricians (or at least those in America) have a strong belief in "powerful others". Not having an RSOC was a predictor of not being screened for breast, colon, or prostate cancers and not having influenza vaccine.

Does a strong belief in "powerful others" for yourself imply, or exclude, a strong belief in yourself as a "powerful other" for others?

ARCHIVIST 